\title{
Zachować dla przyszłości. Sprawozdanie z prac konserwatorsko- restauratorskich prowadzonych przy drukach i rękopisach karaimskich w roku 2015
}

\author{
Małgorzata Pronobis-Gajdzis \\ Uniwersytet Mikołaja Kopernika w Toruniu, Wydział Sztuk Pięknych \\ Zakład Konserwacji Papieru i Skóry
}

To Preserve for the Future.

Report on the Conservation-Restoration Treatment of

Karaim Prints and Manuscripts in 2015

\begin{abstract}
Summary: This report contains information with reference to the conservation work on Karaim manuscripts and old prints carried out in 2015 by Professor Elżbieta Jabłońska and the author of this report Małgorzata Pronobis-Gajdzis, Ph.D. In this report altogether 8 items are presented in detail.
\end{abstract}

Keywords: Karaim old prints, Karaim manuscripts, conservation and restoration of Karaim books, Karaim written heritage

Niniejszy komunikat jest de facto sprawozdaniem z przebiegu prac konserwatorskich-restauratorskich prowadzonych przez autorkę komunikatu i prof. dr hab. Elżbietę Jabłońską przy sześciu rękopisach i starych drukach karaimskich. Projekt został zrealizowany przez Związek Karaimów Polskich z dotacji celowych Ministerstwa Kultury i Dziedzictwa Narodowego w roku 2015. 
Do konserwacji-restauracji wytypowano następujące obiekty:

1. Rękopis będący tzw. medżumą, tj. zbiorem utworów literatury ludowej z Krymu. Rękopis powstał na Krymie w połowie XIX w., niestety - jak dotąd - nie zidentyfikowano jego kopisty. Zbiór zawiera pieśni türkü, fragment eposów Köroglany i Karadżaoglu, poezje pieśniarzy ludowych i poetów mistycznych znanych także ze środkowoazjatyckiego i anatolijskiego kręgu kulturowego, m.in. Aszyka Omera, Gevheriego, Yunusa Emre i inne, co czyni rękopis niezwykle interesującym źródłem do badań porównawczych nad literaturą turecką i turkijską. Obiekt ma wymiary $11,0 \times 17,0 \times 0,5[\mathrm{~cm}]$ i zawiera 34 karty. Niestety nie zachowała się pierwotna oprawa rękopisu. Zabytek oznaczony został nr inw. JSul.I.06. Prace konserwatorskie-restauratorskie wykonała M. Pronobis-Gajdzis.

2. Rękopis zawierający zbiór przekładów trenów Jeremiasza na wymarły już obecnie dialekt południowo-zachodni języka karaimskiego. Jeden z nielicznych zachowanych rękopisów powstałych w Łucku i dokumentujących lokalną odmianę języka karaimskiego. Rękopis został sporządzony przez Zecharię Rojeckiego, który był hazzanem w Łucku w latach 1879-1902. Obiekt ma wymiary 17,1 × 11,7 × 2,6 [cm] i zawiera 132 karty. Oprawiono go w oprawę typu półskórek, zarówno skóra, jak i groszkowany papier są w kolorze ciemnobrązowym. Zabytek oznaczony został nr inw. JSul.I.11. Prace konserwatorskie-restauratorskie wykonała M. Pronobis-Gajdzis.

3. Rękopis zawierający bogaty zbiór przekładów modlitw pokutnych i błagalnych na Jom Kippur (Dzień Pojednania). Materialna substancja zabytku jest nośnikiem wymarłego dialektu południowo-zachodniego języka karaimskiego. Rękopis sporządzony przez znanego kopistę Józefa Mordkowicza (1802-1884). Obiekt, poprzez swoją warstwę treściową i językową, posiada wyjątkowy atrybut naukowości. Artefakt ma wymiary 20,0 × 12,7 × 1,8 [cm]

Zawartość rękopisów przedstawiono na podstawie opisów katalogowych autorstwa Michała Németha (Kraków/Mainz) i Anny Sulimowicz (Warszawa) powstałych w ramach prac nad katalogiem rękopisów karaimskich przechowywanych w polskich zbiorach prywatnych (projekt finansowany przez Narodowe Centrum Nauki, nr rej.: 2011/03/D/HS2/00618). Prace konserwatorsko-restauratorskie w roku 2015 zostały sfinansowane dzięki wsparciu Ministerstwa Kultury i Dziedzictwa Narodowego w ramach projektów 05819/14/FPK/NIMOZ, 05315/15/FPK/NIMOZ oraz 05570/15/ FPK/NIMOZ, a karty katalogowe dostępne są w e-Jazyszłar. Karaimskim Archiwum Cyfrowym. 
i zawiera 48 kart. Oprawa jest półskórkowa, grzbiet i narożniki obleczono skórką cielęcą w kolorze koniakowym, natomiast okładziny ozdobnym papierem galanteryjnym w kolorze żółtym z czarno-pomarańczowymi wzorami. Miejscem powstania rękopisu jest Halicz. Zabytek oznaczono nr inw. JSul.I.12. Prace konserwatorskie-restauratorskie wykonała M. Pronobis-Gajdzis.

4. Rękopis zawierający gramatykę hebrajską w pytaniach i odpowiedziach. Obiekt jest zabytkiem dialektu północno-zachodniego (trockiego) języka karaimskiego. Ponadto stanowi rzadki przykład dzieła o charakterze dydaktycznym. Artefakt powstał w Trokach w 1817 roku. Zabytek ma wymiary 16,3 × 10,1 × 0,9 [cm], zawiera 44 rękopiśmienne karty. Oprawiono go w oprawę typu półskórek, w której wykorzystano zieloną skórę cielęca i ozdobny papier marmurkowy w kolorze oliwkowo-czarnym. Artefakt oznaczono nr inw. JSul.I.20. Prace konserwatorskie-restauratorskie wykonała M. Pronobis-Gajdzis.

5. Drukowany modlitewnik zawierający tom drugi i trzeci modlitewnika wydanego w Kale 1737, czyli jednej z pierwszych wydanych na Krymie drukowanych książek, które wyszły spod prasy karaimskiej drukarni w Kale koło Bachczyseraju. Pomiędzy kartami druku znajdują się wstawki rękopiśmienne z różnych okresów, powstałe w Haliczu i obejmujące pieśni i dodatkowe modlitwy na święta Pesach (Pascha) i Szawuot (Święto Tygodni), posty dziewiątego dnia miesiąca tamuz i dziesiątego dnia miesiąca aw. Rękopis napisano w języku hebrajskim i zachodniokaraimskim (dialekt południowy). Obiekt ma wymiary 22,0 × 17,0 ×6,0 [cm] i zawiera 255 kart, w tym 31 kart rękopiśmiennych. Rękopis oprawiono w deski obleczone brązową skórą. Książka zapinana jest na metalowe klamry. Obiekt oznaczono nr inw. JSul. III.64. Prace konserwatorskie-restauratorskie przy bloku wykonała Elżbieta Jabłońska, prace z zakresu introligatorstwa konserwatorskiego i konserwacji-restauracji oprawy wykonała M. Pronobis-Gajdzis.

6. Modlitewnik drukowany zawierający Seder ha-Tefillot ke-minhag kehal ha-Kara'im. Kanon modlitw w druku ułożony został przez Josefa ben Aharona. Druk wydano w 1528 roku, w Wenecji w oficynie wydawniczej Daniela Bomberga, nakładem Corneliusa Adelkinda. Partie drukowane pochodzą z drugiej części modlitewnika (część pierwsza liczy cztery tomy) zawierającej dodatkowe modlitwy na Jom Kippur, Sukkot (Święto Szałasów), sobotę przed Purim oraz na ślub i sobotę po nim oraz na obrzezanie. Kodeks ma wymiary 20,5 × 15,0 × 6,5 [cm] i zawiera 292 karty, w tym 188 rękopiśmiennych kart z tekstem XVIII/XIX w. (Halicz/Kukizów). Partie rękopiśmienne 
zawierają uzupełniające modlitwy oraz hymny błagalne i pokutne na Jom Kippur w języku hebrajskim i karaimskim (dialekt południowo-zachodni z cechami archaicznymi). Kopiści wstawek rękopiśmiennych są nieznani. Rękopis oprawiono w deski obleczone brązową skórą. Obiekt oznaczono nr inw. JSul.III.66. Prace konserwatorskie-restauratorskie przy bloku wykonała Elżbieta Jabłońska, prace z zakresu introligatorstwa konserwatorskiego i konserwacji-restauracji oprawy wykonała M. Pronobis-Gajdzis.

7. Rękopis zawierający zbiór modlitw i hymnów na święta Paschy, Tygodni, Dzień Pojednania i Święto Namiotów, jak też fragment przekładu Księgi Koheleta. Wiadomo, że rękopis powstał w pierwszej połowie XIX w. w Haliczu, niestety, kopisty jak dotąd nie zidentyfikowano. Obiekt ma wymiary $18,5 \times 11,5 \times 4,0[\mathrm{~cm}]$, zawiera 270 kart. Oprawa rękopisu się nie zachowała. Obiekt oznaczono nr inw. JSul.III.67.

8. Rękopis zawierający przekład niektórych ksiąg Starego Testamentu (Pięcioksiąg Mojżeszowy, księgi Rut, Jeremiasza, Koheleta i Estery) na język zachodniokaraimski. Kopistą był Simcha z Kukizowa syn Chananiela z Derażna, który ukończył pracę nad rękopisem w roku 1720, co czyni ten rękopis najstarszym zachowanym przekładem Starego Testamentu na język zachodniokaraimski, stanowiącym bezcenne źródło dla badań językoznawczych nad dziejami języka karaimskiego i procesu jego podziału na dialekty (południowo-zachodni, którym posługiwali się Karaimi z Łucka i Halicza oraz północno-zachodni używany w skupiskach karaimskich na Litwie). Obiekt ma wymiary 18,2 × 15,5×6,0 [cm] i zawiera 386 rękopiśmiennych kart. Nie zachowała się, niestety, pierwotna oprawa rękopisu. Obecnie obiekt oprawiony jest w dwudziestowieczną oprawę tzw. teczkową obleczoną w brązowe płótno introligatorskie. Jest ona także świadectwem historycznym z czasu swego powstania. Obiekt oznaczono nr inw. III.73 i jest przechowywany w prywatnej kolekcji rękopisów karaimskich w Polsce (właściciel pragnie pozostać anonimowy). Prace konserwatorskie-restauratorskie przy bloku wykonała Elżbieta Jabłońska i M. Pronobis-Gajdzis, prace z zakresu introligatorstwa konserwatorskiego i konserwacji oprawy wykonała M. Pronobis-Gajdzis.

Wszystkie obiekty były ogólnie w złym stanie zachowania, papierowe karty bloków były brudne, z zaciekami i licznymi zaplamieniami niewiadomego pochodzenia, osłabione strukturalnie. Konstrukcje książek najczęściej były znacznie osłabione. Oprawy w dwóch przypadkach się nie zachowały, w czterech przypadkach były wtórne, jedynie w dwóch oryginalne, co zdecydowanie 
podniosło wartość tych rękopisów, jako obiektów w pełni autentycznych i integralnych. Zarówno papier w blokach, jak i obleczenia opraw (zarówno skórzane, jak i papierowe) miały - w wyniku synergicznego działania czynników wewnętrznych i zewnętrznych - znacznie obniżone właściwości strukturalne. Brak opakowań ochronnych narażało obiekty na działanie szkodliwych czynników zewnętrznych - zarówno mechanicznych, jak i fizyko-chemicznych, a także biologicznych. Przyspieszało to ich niszczenie. Opisywane artefakty wymagały zatem natychmiastowej ingerencji konserwatorskiej.

Głównym zadaniem konserwacji - restauracji druków i rękopisów karaimskich było zachowanie ich dla przyszłych pokoleń, poprzez utrwalenie ich materialnej struktury oraz zahamowanie procesów ich destrukcji. Wykonanie projektu konserwacji-restauracji poprzedziły wstępne analizy zabytków, które określiły ich technikę wykonania i stan zachowania. Wyniki tych analiz potwierdziły autentyczność obiektów, dzięki czemu można było rozpoznać ich atrybuty decydujące o poszczególnych wartościach. Ich interpretacja stanowiła punkt wyjścia dla opracowania projektu konserwatorskiego.

Nośnikiem atrybutów rzeczywistych jest substancja pierwotna obiektów. Do atrybutów tej grupy generujących największą wartość należą: historyczność, naukowość, unikatowość i emocjonalność. Wszystkie obiekty są dokumentami historii. Ponadto stanowią bogaty zasób informacji koniecznych do poznania kultury karaimskiej. Informacje te mogą być przedmiotem badań dla językoznawców, biblioznawców, technologów. Warstwa pierwotna obiektów ma ponadto zdolność generowania wartości potencjalnych, takich jak: kulturowość, tożsamość społeczna, duchowość. Tym samym istnieje olbrzymie zapotrzebowanie społeczności karaimskiej na trwanie obiektów w jak najdłuższym czasie, istnienie w przyszłości dla kolejnych pokoleń.

Podstawowym celem przeprowadzanych zabiegów konserwatorsko-restauratorskich było zatem powstrzymanie zachodzących w obiektach procesów destrukcji materiałów oraz zabezpieczenie ich przed dalszym, postępującym niszczeniem. W stosunku do materii pierwotnej powstrzymano się od działań niekoniecznych, np. wyeliminowania istniejących zniszczeń, które w żaden już sposób nie są zagrożeniem dla tej materii. W podejściu do nawarstwień historycznych w pierwszej kolejności kierowano się zasadą, zgodnie z którą w konserwacji-restauracji zabytków należy usunąć to, co działa na obiekt niszcząco.

Wszystkie prowadzone przy obiektach prace zdokumentowano w sposób opisowy i fotograficzny, co zostało szczegółowo przedstawione w dokumentacjach z przebiegu prac konserwatorskich-restauratorskich wykonanych wg obowiązujących standardów branżowych. 
